\title{
IAMJ
}

INTERNATIONAL

AYURVEDIC

MEDICAL JOURNAL

ISSN: 2320-5091

Impact Factor: 6.719

\section{ĀKĀRAKARA AS DERMAL ANAESTHETIC}

\section{Bhavya K.G ${ }^{1}$ George M. J}

${ }^{1} 3^{\text {rd }}$ year PG Scholar, VPSV Ayurveda College, Kottakkal, Kerala

${ }^{2}$ Professor and HOD, Department of Shalya Tantra, VPSV Ayurveda College, Kottakkal, Kerala

Corresponding Author: kgbhavya98@gmail.com

\section{https://doi.org/10.46607/iamj1909112021}

(Published Online: November 2021)

Open Access

(C) International Ayurvedic Medical Journal, India

Article Received: 06/10//2021 - Peer Reviewed: 27/10/2021 - Accepted for Publication: 29/10/2021

\section{Check for updates}

\begin{abstract}
Nowadays, the role of local anaesthesia in the surgical field is highly appraisable. Local anaesthetics are the drugs that produce a loss of sensation over the localised areas without producing a loss of consciousness. Humans have been using various methods to block pain for thousands of years. Controlling pain during the śhastrakarma in śalyatantra has been always challenging. There has been the introduction of various methods of local anaesthetics since the origin of medical science, topical anaesthetics being one of them. Studies have been conducted to discover novel anaesthetic agents by various scholars. Herbal extracts do not stand far in the pathway of this search. Owing to these discoveries, $30 \%$ ethanolic extract gel of Äkärakara (Spilanthes calva DC.) is selected here as a topical anaesthetic to evaluate the efficacy in facilitating the management of warts by a painful procedure agnikarma.
\end{abstract}

Keywords: Dermal anaesthetic, Ākārakara, Spilanthol

\section{INTRODUCTION}

Ācārya Suśruta too had considered anaesthesia as an important part of surgery and for controlling the pain he highly recommended the administration of alcoholic preparations during a surgical procedure. There are various classical references for the management of pain with the usage of Śülapraśamanagaṇa auśadha ${ }^{1}$, administration of madya before the surgeries of aśmari and extraction of mü dhagarbha. ${ }^{2}$ Still, there is no reference found regarding the complete loss of pain during an operative procedure. This has led to a decline in śalyatantra branch of Ayurveda. A topical application is chosen here for the purpose of local anaesthesia as 
it will be patient-friendly, non-invasive and a safer method. Akkärakara is a medicinal plant used widely in Ayurveda, folklore medicine other traditional Indian medicinal systems. It is also applied externally as an analgesic and is found to be safe. ${ }^{3-5}$ Akārakara or Sarāhattika ${ }^{6,7}$ which is used, traditionally belongs to the genus Spilanthes which belongs to the family Asteraceae (formerly Compositae). Spilanthes calva is the most available species of $\bar{A}$ karrakara in southern India, hence it is chosen here. The possible action of Spilanthol, in analogy with the action of local anaesthetics, is suggested to be the blockage of voltagegated sodium channels. Using the ethanolic extract of $\bar{A} k \bar{a}$ rakara as a surface anaesthetic may be used to alleviate the pain inflicted during the para surgical procedures in Shalyatantra such as agnikarma.

\section{Dermal anaesthesia}

Dermal anaesthesia is defined as superficial loss of sensation in the conjunctiva, mucous membranes, or skin, produced by direct application of local anaesthetic solutions, ointments, gels or sprays.

The first local anaesthetic (cocaine) was a topical anaesthetic. This was serendipitously discovered to have anaesthetic properties by Albert Niemann in 1860. He discovered that a newly isolated compound caused the numbing effect of the tongue. ${ }^{8}$ The discovery of various amide and ester local anaesthetics opened the gate of immense possible uses of topical anaesthetics.

\section{Mechanism of Action}

Topical anaesthetics act by reversibly blocking the nerve conduction near their site of administration. They target the free nerve endings in the dermis or mucosa and produce a temporary loss of sensation. The nerve cell membrane permeability to sodium ions is decreased and the nerve impulse conduction is blocked, by competing with calcium-binding sites that control sodium permeability. This decreases depolarization and increases the excitability threshold. Thus, the ability to generate an action potential is lost.

Spilanthes calva D C. ${ }^{9}$

Synonyms: S. acmella auct. non (L.) Murr., S. paniculata auct. non-DC., S. pseudoacmella auct. non (L.) Murr., S. acmella auct. Non (L.) Murr
Acmella calva is the most recent nomenclature given to the drug. ${ }^{10}$

Ayurveda: Marahattikka

Rasa: Katu

Guna: Tikshna, Ruksha, Laghu

Virya: Ushna

Vipaka: Katu

Karma: KaphaVata hara, Danta sula, sula roga

Spilanthol

Spilanthol is an $\mathrm{N}$-alkylamide, a bioactive compound that is found in different plants. The plants in which it is found are often called toothache plants, due to the analgesic effect of spilanthol. ${ }^{11}$ Alkamides including spilanthol has a strong, pungent taste and produce local astringency and anaesthetic effects. Alkamide compounds produce tingling sensation in the mouth. It has been shown that the fatty acid part of alkamides strongly influences its sensorial action. The tingling effect may be mediated by different ion-channel receptors on different types of sensory neurons, like the capsaicin (transient receptor potential vanilloid type 1 (TRPV1)), TRPA1, TRPM8 receptor, while more recently, emphasis is placed on distinct receptors like KCNK3, KCNK 9 and KCNK 18 (two-pore potassium channels). ${ }^{12}$

Akarakara Gel

Part of drug used- Whole plant

Prepared at Research and Development, P.S. Varier's Arya Vaidya Sala, Kottakkal.

- The gel prepared will have a $30 \%$ w/w concentration of extract in it.

\section{Method of Processing:}

- $500 \mathrm{~g}$ of raw material was weighed accurately and soaked in 2 litres (50:50 hydro alcoholic) solvent.

- The soaked material was boiled for 1 hour.

- The extract was filtered.

- The process was repeated 3 times.

- The extract obtained in the 3 extractions were further concentrated to paste and then dried in a hot air oven.

- The dried extract was used for Gel processing.

- The extract was dissolved in Distilled water.

- Required quantity of Carbomer was dispersed in Distilled water. 
- The preservative was added to the dispersed Carbomer.

- Dissolved extracts are then added to the Carbomer.

- Glycerin was added to the mixture.

- It was then uniformly mixed.

- $\mathrm{pH}$ was adjusted to 7 with a suitable buffer.

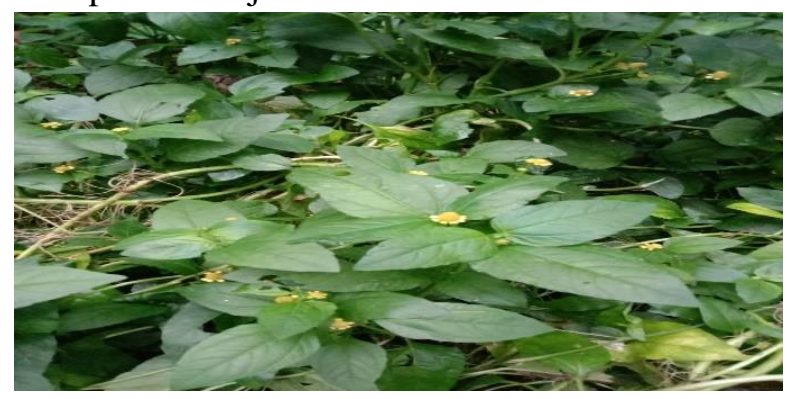

\section{Methodology}

The study setting was Shalyatantra OPD of VPSV Ayurveda College, Kottakkal. 15 participants satisfying the diagnostic, inclusion and exclusion criteria were selected for the study.

a) Diagnostic criteria

Based on signs and symptoms

b) Subject inclusion criteria

1. Warts with a base diameter up to $5 \mathrm{~mm}$.

2. Irrespective of gender in the age group of 21-60 years.

3. Subjects with informed consent.

4. Subjects in whom agnikarma is indicated as per Classics.

c) Subject exclusion criteria
1. Warts are associated with any other skin lesion.

2. Warts on the plantar surface, palmar surface and face.

3. Known cases of - Uncontrolled Diabetes Mellitus and Hypertension, Bleeding disorders, Acute Immuno-Deficiency Syndrome, Carcinoma, Epilepsy, Stroke, Allergy to anaesthetics.

4. Subjects under medications for warts.

- The subjects were informed regarding the procedure and consent was recorded.

- Pūrva karma - The subject was advised to take a light diet.

- The part was prepared and draped with a sterile towel and a clean region was exposed for the intervention.

- The gel was applied in an area of $2 \mathrm{~cm}$ radius from the centre of the lesion.

- Waited for 20 minutes for the probable initiation of action of the local anaesthetic.

- Agnikarma was done according to SOP using panchadhātu śalāka.

- The assessment was carried out USING a Numerical rating scale, Behavioural rating scale, Wong Bakers faces pain scale and pulse oximeter.

- Paścat karma - Equal quantities of ghee and honey were applied over the site of agnikarma.

Duration - 1 day

Follow up - Conventional treatment for warts as an OPD management.

Table 1: Mean pain values in each minute

\begin{tabular}{|l|l|l|l|l|}
\hline Minutes & Numerical rating scale & Behavioural rating scale & Wong Baker faces pain scale & Pulse rate \\
\hline M0 & $3.5000 \pm 3.5$ & $5.2667 \pm 1.5$ & $2.2143 \pm 2.21$ & $78.8000 \pm 16.05$ \\
\hline M1 & $3.2143 \pm 3.2$ & $1.9333 \pm 1.22$ & $2.5000 \pm 2.50$ & $78.7333 \pm 13.5$ \\
\hline M2 & $1.6429 \pm 1.6$ & $1.0000 \pm 0.36$ & $1.0000 \pm 1.00$ & $79.0667 \pm 10.8$ \\
\hline M3 & $.7857 \pm 0.78$ & $.3333 \pm 0.81$ & $.3571 \pm 0.35$ & $76.9333 \pm 9.2$ \\
\hline M4 & $.5000 \pm 0.50$ & $.1333 \pm 0.51$ & $.1429 \pm 0.14$ & $72.8667 \pm 5.91$ \\
\hline M5 & $.2857 \pm 0.28$ & $.1333 \pm 0.35$ & $.2143 \pm 0.21$ & $72.2000 \pm 3.8$ \\
\hline M6 & $.2857 \pm 0.28$ & $.4000 \pm 0.63$ & $.5714 \pm 0.57$ & $71.9333 \pm 3.4$ \\
\hline M7 & $.0714 \pm 0.07$ & $.5333 \pm 1.91$ & $.5000 \pm 0.500$ & $71.7333 \pm 3.4$ \\
\hline M8 & $1.1429 \pm 1.14$ & $.9333 \pm 1.03$ & $.6429 \pm 0.64$ & $72.1333 \pm 3.8$ \\
\hline M9 & $1.7143 \pm 1.71$ & $1.5333 \pm 1.40$ & $1.2857 \pm 1.28$ & $74.8667 \pm 5.2$ \\
\hline M10 & $1.714 \pm 1.71$ & $2.3333 \pm 44$ & $1.7143 \pm 1.7$ & $75.0000 \pm 5.3$ \\
\hline
\end{tabular}


Table 2: Mean difference in pain value between the minutes

\begin{tabular}{|c|c|c|c|c|c|c|c|c|}
\hline & \multicolumn{2}{|c|}{ Numerical rating scale } & \multicolumn{3}{|c|}{ Behavioural rating scale } & Wong Baker faces pain scale & cale Puls & Pulse rate \\
\hline $\begin{array}{l}\text { Between } \\
\text { minutes }\end{array}$ & $\begin{array}{l}\text { Mean Differ- } \\
\text { ence }\end{array}$ & $\mathrm{p}$-value & $\begin{array}{l}\text { Mean Dif- } \\
\text { ference }\end{array}$ & $\mathrm{p}$-value & $\begin{array}{l}\text { Mean Dif- } \\
\text { ference }\end{array}$ & p-value & $\begin{array}{l}\text { Mean Dif- } \\
\text { ference }\end{array}$ & p-value \\
\hline $\mathrm{M} 0 * \mathrm{M} 1$ & .286 & $\mathrm{p}>0.05$ & $3.333^{*}$ & $\mathrm{p}<0.05$ & -.286 & $\mathrm{p}>0.05$ & .067 & $\mathrm{p}>0.05$ \\
\hline $\mathrm{M} 1 * \mathrm{M} 2$ & $1.571^{*}$ & $\mathrm{p}<0.05$ & .933 & $\mathrm{p}>0.05$ & $1.500^{*}$ & $\mathrm{p}<0.05$ & -.333 & $\mathrm{p}>0.05$ \\
\hline $\mathrm{M} 2 * \mathrm{M} 3$ & .857 & $p>0.05$ & .667 & $p>0.05$ & .643 & $p>0.05$ & 2.133 & $\mathrm{p}>0.05$ \\
\hline $\mathrm{M} 3 * \mathrm{M} 4$ & .286 & $p>0.05$ & .200 & $p>0.05$ & .214 & $p>0.05$ & 4.067 & $\mathrm{p}>0.05$ \\
\hline M4*M5 & .214 & $p>0.05$ & .000 & $\mathrm{p}>0.05$ & -.071 & $\mathrm{p}>0.05$ & .667 & $\mathrm{p}>0.05$ \\
\hline M5*M6 & .000 & $p>0.05$ & -.267 & $p>0.05$ & -.357 & $p>0.05$ & .267 & $\mathrm{p}>0.05$ \\
\hline M6*M7 & .214 & $p>0.05$ & -.133 & $p>0.05$ & .071 & $\mathrm{p}>0.05$ & .200 & $\mathrm{p}>0.05$ \\
\hline $\mathrm{M} 7 * \mathrm{M} 8$ & $-1.071^{*}$ & $\mathrm{p}<0.05$ & -.400 & $\mathrm{p}>0.05$ & -.143 & $\mathrm{p}>0.05$ & -.400 & $p>0.05$ \\
\hline M8*M9 & -.571 & $p>0.05$ & -.600 & $p>0.05$ & -.643 & $p>0.05$ & -2.733 & $\mathrm{p}>0.05$ \\
\hline M9*M10 & .000 & $p>0.05$ & -.800 & $p>0.05$ & -.429 & $p>0.05$ & -.133 & $\mathrm{p}>0.05$ \\
\hline
\end{tabular}

Figure 1

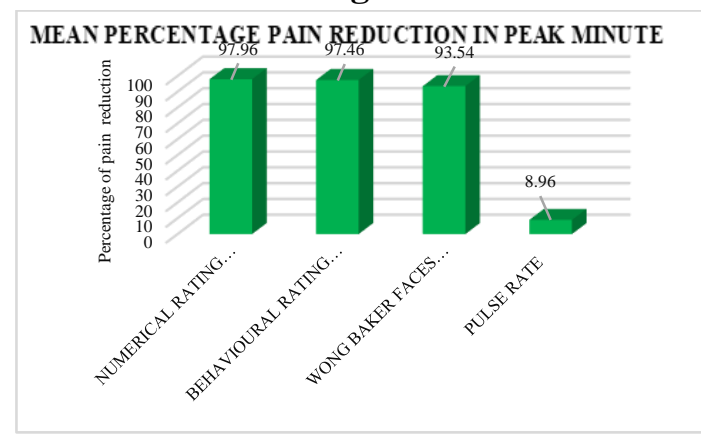

Figure 2

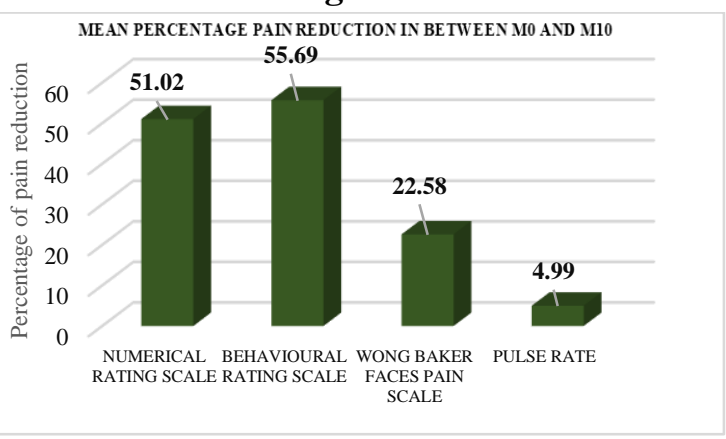

Result: The $30 \%$ ethanolic extract gel of Akarakara is effective in reducing pain during the agnikarma.

\section{DISCUSSION}

The history of anaesthesia is related to the history of surgery from the Vedic period up to the modern era. Susrutha, the father of surgery, has mentioned the use of wine ${ }^{4}$ preoperatively which is the only reference mentioned to reduce pain. An intoxicated person does not feel the pain of the surgical procedure. Acharya Charaka also mentioned the use of wine during the extraction of Müdhagarbha. ${ }^{13}$

Lack of general, as well as local anaesthesia, is the main reason for the loss of popularity of Sastrachikitsa in Ayurveda, resulting in the practice of few minor Sasrakarma and Anushastra karma in the present-day ayurvedic surgery. Previously, surgical procedures were carried out with the help of available drugs that helped in minimising pain. All the possible techniques and drugs such as Vedanasthapaka Gana, Madya, Sammoha churna were tried. ${ }^{14}$ Not enough pharmacological evidence that could be explained in parallel to the conservative medicine was available. The initial practice of anaesthesia was using the aqueous and other extracts of plants such as opium and mandragora. ${ }^{15}$ Surgical branches of medicine grew exponentially after the discovery of anaesthesia. In the branch of Ayurveda, this sector did not see much development. This is the reason why śalyatantra limited or restricted the disease management by sastra widely. Currently, minor procedures like Chedana, Bhedana are done in appropriate cases without the usage of anaesthetic drugs. Local anaesthesia on intact skin is of growing importance given the increased use of minor surgical procedures on an out-patient basis. Specific 
pain receptors (nociceptors) are responsible for sensing cutaneous pain. Local anaesthetics reversibly lock the nociception. Effective routes of administration are dermal infiltration or, more recently, anaesthesia by topical application of specifically formulated preparations that promote percutaneous absorption of the drug (percutaneous local anaesthesia). ${ }^{16}$ In the present study, in this work as an endeavour towards finding a solution to this problem, a sample containing 30\% ethanolic extract of $\bar{A} k \bar{a}$ rakara in the form of gel was selected for the study to find out if it has an anaesthetic effect. As per the dissertation conducted by Dr K.B. Sudhikumar in 1987, alcoholic extract of Aparajitha was more effective than water extract. ${ }^{17}$ Resins, volatile oils, alkaloids, glycosides etc. are dissolved in alcohol while other therapeutically inert substances as gum, albumin, and starch are insoluble in it, which make alcohol a good solvent. Spillanthes species contain the N-alkylamide spilanthol which has been previously proved to have skin penetrating activity and oral anaesthetic properties. So, the drug which contained spilanthol was selected here. The widely used Spilanthes species in the previous studies was Spilanthes acmella and Spilanthes oleracea. The Indian species found abundantly is Spilanthes calva DC. Taking feasibility into consideration, the Spilanthes calva DC was selected here. Spilanthol is the chemical molecule that helps in the anaesthetic activity of the drug. Spilanthol presents good stability in ethanolic extracts. ${ }^{18}$ The mechanism of action of spilanthol in blocking the voltage-gated sodium channel was studied earlier. The penetration action of spilanthol through the human stratum corneum and epidermis was also studied. ${ }^{19}$ The drug Ākärakara (Spilanthes calva DC.) is kațu rasa pradhana, of laghu guna and has ushna virya. The local action of the drug as an anaesthetic cannot be explained using rasa panchaka. Although, the literature supports that Ākärakara is having vātakapha hara karma. ${ }^{20}$ Ashtanga hrudaya supports that, if karma cannot be explained using rasadi guna, it is because of prabhava. Twak is the sthana of vāta. The vedana gyana is due to the karma of vāta on twak. Here, from the prabhava of the drug, vedana haani is seen due to vātashamana. Hence, there will be impairment in cutaneous sensation. In the context of pralepa, the explanation of drugs being absorbed through lomakupa is told. ${ }^{21}$ Moreover, the absorption may be improved by covering the application area with a dressing or a patch. In this study, an adhesive dressing was applied over the lepa at the site for up to 20 minutes to enhance the absorption. The average onset of action of the local anaesthetic was assumed to be 20 minutes from the previous studies that reported the onset of action of dermal anaesthesia from 15 minutes to one hour. The pharmacokinetics and disposition of alkylamides have been investigated after oral use, indicating that the alkylamides present in Echinacea preparations shows a rapid oral absorption ranging between 10 and $40 \mathrm{~min}$. This can be substantiated with our observation where the anaesthetic action was not maintained in the trial drug after 30 minutes of application. ${ }^{22}$ Spilanthol, supplied as a 30 w/w\% ethanolic Spilanthes acmella flowers extract studied and was found that $91 \%$ of the total amount of $\mathrm{N}$-alkylamides in the extract was identified as spilanthol. ${ }^{19}$ The analgesic activity of spilanthol has been attributed to an increased GABA release in the temporal cerebral cortex, while Echinacea alkylamides are acting on voltage-gated sodium channels. ${ }^{19}$

\section{CONCLUSION}

The total efficacy of the drug in reducing pain during the treatment was found to be $70.17 \%$. When pain reduction is assessed, the total percentage of anaesthetic activity sustained is $33.57 \%$. The anaesthetic activity of the drug is not sustained for a longer duration.

\section{Recommendation}

Studies are recommended using a higher concentration of Spillanthes calva DC. extracts.

\section{REFERENCES}

1. Trikamji Y. (ed.). Nibandhasamgraha Tika of Dalhana on Sushruta Samhita Sutrasthana. $1^{\text {st }}$ edition, Varanasi: Krishnadas Academy;1998;83. (Chapter 17, verse no. 11-12)

2. Boonen J, Baert B, Roche N, Burvenich C, De Spiegeleer B. Transdermal behaviour of the $\mathrm{N}$-alkylamide 
spilanthol (affinin) from Spilanthes acmella (Compositae) extracts. Journal of Ethnopharmacology. 2010 Jan 8;127(1):77-84.

3. Boonen J, Baert B, Roche N, Burvenich C, De Spiegeleer $\mathrm{B}$. Transdermal behaviour of the $\mathrm{N}$-alkylamide spilanthol (affinin) from Spilanthes acmella (Compositae) extracts. Journal of Ethnopharmacology. 2010 Jan 8;127(1):77-84.

4. Pandey G. Dravya guna vigyana. 3rd ed. Part I. Varanasi. Chaukamba Krishnadas Academy; p.87-90.

5. Ayurvedic Pharmacopeia of India, part I, Vol II, 1st ed., Government of India, Ministry of Health and family welfare, Dept of ISMH, p.1.

6. IndiaNetzone.Sarahattika, Indian medicinal Plant. Available from: [https://www.indianetzone.com/38/sarahattika_plant.htm ]

7. Ved RK. (Late), Suma Tagadur Sureshchandra, Vijay Barve, Vijay Srinivas, Sathya Sangeetha, K. Ravikumar, Kartikeyan R., Vaibhav Kulkarni, Ajith S. Kumar, S.N. Venugopal, B. S. Somashekhar, M.V. Sumanth, Noorunissa Begum, Sugandhi Rani, Surekha K.V., and Nikhil Desale. (eds.) 2016. (envis.frlht.org / frlhtenvis.nic.in). FRLHT's ENVIS Centre on Medicinal Plants, Bengaluru. Copyright: FRLHT, Bengaluru and MoEFCC, GoI. Last Updated: Monday, 4th March 2019 [http://envis.frlht.org]

8. Biscoping J, Bachmann-Mennenga MB. Local anesthetics from ester to isomer. Anasthesiol Intensivmed Notfallmed Schmerzther. 2000; 35:285-92.

9. Anonymous, 2013, http://data.gbif.org/species/browse/taxon/13219744/, R. A. Harold, M. Powell, R. M. King et al., "Chromosome numbers," in Compositae, XII: Heliantheae, Smithsonian Institution Press, Washington, DC, USA, 1981.View at: Google Scholar.

10. Board of Trustees of the Royal Botanic Gardens. Plants of the World online. [Internet]. Kew: R.K Jansen; [cited 2021 aug 15] Available from: http://www.plantsoftheworldonline.org/results?q=Spilanthes\%20calva

11. De Spiegeleer B, Boonen J, Malysheva SV, Di Mavungu JD, De Saeger S, Roche N, Blondeel P, Taevernier L, Veryser L. Skin penetration enhancing properties of the plant $\mathrm{N}$-alkylamide spilanthol. Journal of ethnopharmacology. 2013 Jun 21;148(1):117-25.

12. Boonen J, Halet E, Burvenich C, Blondeel P, De Spiegeleer B. Transdermal behaviour of the $\mathrm{N}$-alkylamide spilanthol. 2009.

13. Acharya Ambika Datta Shastri, ed. Sushruta Samhita Sutrasthana of Susrutha (Ayurveda Tatva Sandipika, comme, Hindi), 13th edition, Varanasi: Chowkhambha Sanskrit Sansthan, 2002. 17/11

14. Chunekar KC, Pandey GS, ed. Bhavaprakasha Nighantu of Bhavamishra. Varanasi: Chaukhambha Bharati Academy. 2010:779 - 88.

15. Kashikar CG. INDIAN MEDICINE IN THE CLASSICAL AGE

16. Adriani J, Dalili H. Penetration of local anaesthetics through epithelial barriers. Anesth Analg. 1971; 50:834-41.

17. K.B Sudhikumar et al., In vivo studies on the culminative effect of indigenous herbal local anaesthetic formūlation. 2012.

18. Boonen J, Baert B, Burvenich C, Blondeel P, De Saeger $\mathrm{S}$, De Spiegeleer B. LC-MS profiling of $\mathrm{N}$-alkylamides in Spilanthes acmella extract and the transmucosal behaviour of its main bio-active spilanthol. Journal of pharmaceutical and biomedical analysis. 2010 Nov 2;53(3):243-9.

19. De Spiegeleer B, Boonen J, Malysheva SV, Di Mavungu JD, De Saeger S, Roche N, Blondeel P, Taevernier L, Veryser L. Skin penetration enhancing properties of the plant $\mathrm{N}$-alkylamide spilanthol. Journal of ethnopharmacology. 2013 Jun 21;148(1):117-25.

20. Medicinal use of Indian Akarkara (Spilanthes acmella). [Available from: https://www.bimbima.com/ayurveda/medicinal-use-of-akarkara-spilanthes-acmella/1383/ ]. Accessed on: 27th February 2019.

21. Sushruta, Sushruta Samhita, Sutra sthana, 17, 6/20, edited with Sushrutavimarshini, Hindi Commentary along with special deliberation by Dr Anant Ram Sharma. $1{ }^{\text {st }}$ ed. Varanasi: Chaukhamba Sura Bharati Prakashan; 2001

22. Boonen J, Baert B, Burvenich C, Blondeel P, De Saeger $\mathrm{S}$, De Spiegeleer B. LC-MS profiling of N-alkylamides in Spilanthes acmella extract and the transmucosal behaviour of its main bio-active spilanthol. Journal of pharmaceutical and biomedical analysis. 2010 Nov 2;53(3):243-9.

\section{Source of Support: Nil Conflict of Interest: None Declared}

How to cite this URL: Bhavya K.G.: Ākärakara As Dermal Anaesthetic. International Ayurvedic Medical Journal \{online\} 2021 \{cited November 2021\} Available from: http://www.iamj.in/posts/images/upload/2764_2768.pdf 